\title{
Factors that Influence the Appearance of Post-puncture Dural Headache in Patients Undergoing Elective Cesarean Section
}

\section{Graciela María Frías Carrazana*, Yacnira Martínez Bazán, Yurisnel Ortiz Sánchez, Secundino González Pardo, Bernardo Blanco-Zamora and Sandra Blanco Martínez}

University Hospital Carlos Ma. De Céspedes, Bayamo, Cuba

*Corresponding author: Graciela María Frías Carrazana, University Hospital Carlos Ma. De Céspedes, Bayamo, Cuba, Tel: 5323425012; E-mail: yacnibernard@gmail.com

Received date: September 13, 2018; Accepted date: November 27, 2018; Published date: November 30, 2018

Citation: Carrazana GMF, Bazán YM, Sánchez YO, Pardo SG, Zamora BB, et al. (2018) Factors that Influence the Appearance of Post-puncture Dural Headache in Patients Undergoing Elective Cesarean Section. Int J Anesth Pain Med Vol No:5 Iss No:1:1

Copyright: (c) 2018 Carrazana GMF, et al. This is an open-access article distributed under the terms of the Creative Commons Attribution License, which permits unrestricted use, distribution, and reproduction in any medium, provided the original author and source are credited.

\section{Abstract}

An epidemiological, observational, analytical and retrospective study of cases and controls was conducted with women undergoing elective cesarean section under spinal anesthesia at the Carlos Manuel de Céspedes Hospital in Bayamo, Granma province, from February 2013 to December 2015; with the objective of identifying the risk factors hypothetically related to the appearance of postpuncture dural headache in obstetric patients undergoing elective cesarean section.

All the patients who gave their consent to participate, their data collection form was prepared for the study that collected the variables of the study. In addition, with each hypothetically influencing factor, the estimate of the benefit frame (OR) and its $95 \%$ confidence intervals $(95 \% \mathrm{Cl})$ and the hypothesis test of Chi to Square were performed. The age less than 25 years, the history of previous headache, the diameter of the needle of 20 and $22 \mathrm{G}$, the greater number of puncture attempts and the position of the seated patient are the risk factors related to the appearance of post-puncture headache dural, but not the body mass index higher than 30 in obstetric patients undergoing elective cesarean section.

\section{Keywords:}

Headache post-puncture; Caesarean section;

Pregnancy

\section{Introduction}

Spinal anesthesia is one of the oldest forms of regional anesthesia.

Dr. August Bier of the University of Berlin, was the first to perform a true spinal anesthesia in 1898, using a Quincke type needle and 10-15 mg of cocaine; as a consequence, the patient developed an intense headache after the operation [1].

It is defined as a scientific problem: What are the risk factors hypothetically related to the appearance of post-puncture dural headache in obstetric patients undergoing elective cesarean section?

\section{Objectives}

\section{General objectives}

Identify the risk factors hypothetically related to the appearance of post-puncture dural headache in obstetric patients undergoing surgery by elective caesarean section.

\section{Specific objectives}

Determine if there is an association between the risk factors dependent on the patient: age, history of previous headache, body mass index; with the appearance of post-puncture dural headache in obstetric patients undergoing elective cesarean section.

Determine if there is an association between the risk factors dependent on the technique: the diameter of the needle, the number of puncture attempts, and the position of the patient; with the appearance of post-puncture dural headache in obstetric patients undergoing elective cesarean section.

\section{Methodological Design}

\section{General characteristics of the research}

An epidemiological, observational, analytical and retrospective study of cases and controls was conducted with women undergoing elective cesarean section under spinal anesthesia at the Carlos Manuel de Céspedes Hospital in Bayamo, Granma province, in the period from February 2013 to December 2015.

\section{Selection of the universe and study sample}

Universe: The universe consisted of 1368 obstetric patients undergoing cesarean section in the Obstetrics-Gynecology 
department of the Carlos Manuel de Céspedes Hospital in Bayamo during the study period.

Sample: Based on the study universe, a probabilistic sample was taken and the selection of cases and controls was carried out by simple random sampling. For the calculation of the size of the final sample, a study of unpaired cases and controls with a non-sick-diseased relationship was designed (2: 1).

Establishing a prevalence of the exposure factor in the nonsick group of $33 \%$ and in the sick group of $23 \%$ with a $95 \%$ confidence coefficient that is equal to a 0.05 level of significance of the error, with a power of $80 \%(1-\beta)$. The statistical package Epi Info version 2002 for Windows was used to calculate the sample size. Establishing the sample size of 192 healthy and 96 patients [2].

\section{Criteria for the selection of cases}

Case is defined to all obstetric patients, with clinical diagnosis of post-puncture dural headache, defined as: A bilateral headache that develops within 5 days after the completion of PL and disappears in a week. The headache occurs or worsens in the standing position and disappears or improves after lying down [3].

\section{Selection criteria for controls}

The controls were selected from a simple random sampling, through which 2 patients of equal age were chosen in the same place and the same period of time, with the same characteristics; After the clinical examination, there were no signs or symptoms of the disease under study.

\section{Criteria for inclusion of cases}

- Obstetric patients from 15 to 45 years undergoing cesarean section in whom spinal anesthesia was administered.

- Patients ASA21 I-II.

- Patients who presented dural post-puncture headache that have been cataloged in the informatics clinical history as such or that meet the criteria of the same.

- Patients who agreed to participate in the study

\section{Exclusion criteria}

- Patients with an associated nosological entity that could cause headache (hypertension induced by pregnancy, preeclampsia, among others).

- Patients with communication difficulties.

\section{Sources of data collection and processing}

The primary information was obtained from the clinical records of patients who underwent elective cesarean section in the delivery room of the University Hospital "Carlos Manuel de Céspedes" with the diagnosis of post-puncture dural headache. The collection of the primary data was carried out by two specialists separately and then the data were compared [4] They were included in a form created for this purpose (Annex 1), which included the selected variables. These variables were subsequently emptied into a database created in SPSS version [5].

\section{Statistical analysis}

Univariate analysis: The estimate of the advantage ratio, known as Odd Ration (OR) and its 95\% confidence intervals (95\% $\mathrm{Cl})$, was also carried out with each hypothetically influential factor. In the variables in which the risk was significantly greater than 1, a hypothesis test of Chi to Square was carried out, with a significance level of $p$ less than 0.05. We tested the hypothesis that the population RR was significantly greater than 1 , to be considered a risk factor.

Multivariate analysis: To determine the independent influence of each factor, when a group of them was present, a multivariate analysis was performed, using the logistic regression technique. The variables were quantified by presenting absolute and percentage values the contingency coefficient was calculated, to statistically evaluate the relationship between the variables. In all cases a level of statistical significance equal to $95 \%$ was selected. The adjustment of the logistic regression function, which is equivalent to the estimation of its parameters, was performed by the maximum likelihood method [6]. The goodness-of-fitness statistic of Hosmer-Lemeshow was also applied to evaluate the goodness of fit of the model.

\section{Ethical Aspects}

The research was approved by the Scientific Council of the institution and its Ethics Committee.

It is developed taking into account the ethical principles and guidelines developed on biomedical research in human beings in the international field such as the Nuremberg Code of 1947, the Helsinki Declaration, Finland enacted in 1964 and approved in the 18th World Medical Assambly corrected by the 29 in Tokyo, Japan in October 1975; the 35 of Venice, Italy in October of 1983; 41 in Hong Kong, September 1989 as well as the 52nd General Assembly in Edinburgh, Scotland in October 2000; Other documents that the Norman are the International Guidelines for Biomedical Research Related to Human Beings proposed in 1982, the Council of International Organizations of Medical Sciences (COICM) and the World Health Organization (WHO) [7].

For the development of the research, the informed consent of the patients and/or their relatives was available to participate in it, respecting their rights and the person, as well as respect for their well-being, for which information was offered necessary that allowed him to decide if he participated in the execution of the tasks of the investigation proper to his status and by will.

The data were taken from the practice and no manipulations were made or therapeutic measures were not proved in the patients. The confidentiality of the data was respected.

\section{Results}

Table 1 describes the distribution of patients who participated in the research according to age, with patients younger than 25 
years of age in both groups being more frequent in the study: the group of cases, 78 patients $(27.08 \%)$, while in controls, 98 patients $(34.02 \%)$. Significant results from the statistical point of view when applying the Chi square test, with a 95\% reliability; as well as a strong association between age under 25 years and the appearance of dural post-puncture headache $(O R=4.16)$, being considered a risk factor.

Although the number of patients with a body mass index greater than 30 prevailed in both groups, 49 patients $(17.01 \%)$ in the group of cases and 97 patients (33.68\%) in the controls, results that are shown in Table 1 ; when applying the Chi square test, with a 95\% reliability, statistically insignificant results were obtained, and a weak association force was established between it and the occurrence of post-dural puncture headache $(O R=1.02)$, what is not considered a risk factor in our study.

Table 1 shows the distribution of patients according to the history of previous headache (75 patients, $26.04 \%$ in the cases, 93 patients, $32.29 \%$ in the controls). Significant results from the statistical point of view when applying the Chi square test, with a $95 \%$ reliability; as well as a strong association between the personal history of headache and the appearance of dural postpuncture headache $(\mathrm{OR}=3.8)$, being considered a risk factor [8].

Table 1. Risk factors dependent on the patient. Univariate analysis 2013-2015.

\begin{tabular}{|c|c|c|c|c|c|c|c|c|c|c|}
\hline \multirow{2}{*}{\multicolumn{2}{|c|}{ FR }} & \multicolumn{2}{|c|}{ Case (96) } & \multicolumn{2}{|c|}{ Control (192) } & \multicolumn{2}{|c|}{ Total (288) } & \multirow{4}{*}{$\begin{array}{l}\text { OR } \\
4.16\end{array}$} & \multirow{4}{*}{ 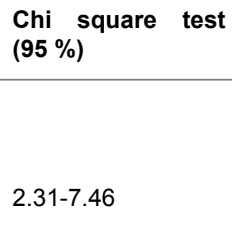 } & \multirow{4}{*}{$\begin{array}{l}\text { probability } \\
0.000\end{array}$} \\
\hline & & \multirow{2}{*}{$\begin{array}{l}\text { No } \\
78\end{array}$} & \multirow{2}{*}{$\begin{array}{l}\% \\
27.08\end{array}$} & \multirow{2}{*}{$\begin{array}{l}\text { No } \\
98\end{array}$} & \multirow{2}{*}{$\begin{array}{l}\% \\
6.3\end{array}$} & \multirow{2}{*}{$\begin{array}{l}\text { No } \\
176\end{array}$} & \multirow{2}{*}{$\begin{array}{l}\% \\
61.11\end{array}$} & & & \\
\hline & $<25$ & & & & & & & & & \\
\hline & $\geq 25$ & 18 & 6.25 & 94 & 33 & 112 & 39.88 & & & \\
\hline \multirow{2}{*}{$\begin{array}{l}\text { body mass } \\
\text { index }\end{array}$} & $\geq 30$ & 49 & 17.01 & 97 & 34 & 146 & 50.69 & \multirow{2}{*}{1.02} & \multirow{2}{*}{$0.63-1.67$} & \multirow{2}{*}{0.9668} \\
\hline & $<30$ & 47 & 16.31 & 95 & 33 & 142 & 49.3 & & & \\
\hline $\begin{array}{l}\text { History of } \\
\text { previous } \\
\text { headache }\end{array}$ & And & 75 & 26.04 & 93 & 32 & 168 & 58.33 & 3.8 & $2.17-6.66$ & 0.000 \\
\hline
\end{tabular}

In Table 2, the diameter of the needle and the occurrence of post-dural puncture headache in patients are described as the object of study; it was presented in 84 patients who used needles with diameter (20 and 22G) dural post-puncture headache in the group of cases and 82 patients in the controls. Significant results from the statistical point of view, considering that in patients where 20 and $22 \mathrm{G}$ needles are used, they have a 9.39 times greater risk factor of developing dural post-puncture headache.

The behavior of the number of puncture attempts is described in Table 2: 75 patients in the group of cases underwent two or more attempts, and they were 4.79 times more likely to develop post-dural puncture headache than those who only had one tried [9]. Significant results from the statistical point of view when applying the Chi square test.

Table 2 shows the behavior of the patient's position at the time of starting the lumbar puncture in the sample studied: 67 patients in the cases; 98 patients, in the controls, in addition these patients have 2.22 times higher risk of suffering post-dural puncture headache. Significant results from the statistical point of view when applying the Chi square test.

\begin{tabular}{|c|c|c|c|c|c|c|c|c|c|c|}
\hline \multicolumn{2}{|l|}{ FR } & \multicolumn{2}{|c|}{ Case (96) } & \multicolumn{2}{|c|}{ Control (192) } & \multicolumn{2}{|c|}{ Total (288) } & \multirow{4}{*}{$\begin{array}{l}\text { OR } \\
9.39\end{array}$} & \multirow{4}{*}{$\begin{array}{l}\begin{array}{l}\text { Chi square test } \\
(95 \%)\end{array} \\
4.81-18.33\end{array}$} & \multirow{4}{*}{$\begin{array}{l}\text { probability } \\
0.000\end{array}$} \\
\hline & & \multirow{2}{*}{$\begin{array}{l}\text { No } \\
84\end{array}$} & \multirow{2}{*}{$\begin{array}{l}\text { \% } \\
29.16\end{array}$} & \multirow{2}{*}{$\begin{array}{l}\text { No } \\
82\end{array}$} & \multirow{2}{*}{$\begin{array}{l}\% \\
28.47\end{array}$} & \multirow{2}{*}{$\begin{array}{l}\text { No } \\
166\end{array}$} & \multirow{2}{*}{$\begin{array}{l}\% \\
58\end{array}$} & & & \\
\hline Diameter of the & 20 y $22 \mathrm{G}$ & & & & & & & & & \\
\hline needle & 24 y $27 G$ & 12 & 4.16 & 110 & 38.19 & 122 & 42 & & & \\
\hline \multirow{2}{*}{$\begin{array}{l}\text { Number of } \\
\text { puncture attempts }\end{array}$} & Two or more & 75 & 26.04 & 82 & 28.47 & 157 & 55 & \multirow{2}{*}{4.79} & \multirow{2}{*}{$2.73-8.40$} & \multirow{2}{*}{0.000} \\
\hline & One & 21 & 7.29 & 110 & 38.19 & 131 & 45 & & & \\
\hline \multirow{2}{*}{$\begin{array}{l}\text { Position of the } \\
\text { patient }\end{array}$} & Seated & 67 & 23.26 & 98 & 34.02 & 165 & 57 & \multirow{2}{*}{2.22} & \multirow{2}{*}{$1.32-3.73$} & \multirow{2}{*}{0.000} \\
\hline & $\begin{array}{l}\text { Lateral } \\
\text { decubitus }\end{array}$ & 29 & 10.06 & 94 & 32.63 & 123 & 43 & & & \\
\hline
\end{tabular}

Table 3 shows the results of the multivariate binary logistic regression analysis; where it can be confirmed that the age is less than or equal to 20 years $(O R=4,120)$, personal pathological history $(O R=3,643)$, the sitting position $(O R=4,484)$, two or more puncture attempts $(O R=6,200)$, as the use of needle 20 and $22 \mathrm{G}$ $(\mathrm{OR}=6,120)$ were risk factors to develop dural post-puncture headache [10]. 
In addition, patients with personal medical history, age less than 20 years and two or more puncture attempts have a 4 times higher risk $(\mathrm{OR}=4,484)$ of developing post-dural puncture headache than those where these risk factors do not coincide.

Table 3. Risk factors associated with the appearance of post-dural puncture headache in obstetric patients undergoing elective cesarean section. Multivariate analysis 2013 - 2015

\begin{tabular}{|c|c|c|c|c|c|c|c|}
\hline \multirow[b]{2}{*}{ Indicators } & \multirow[b]{2}{*}{ B } & \multirow[b]{2}{*}{ E.T. } & \multirow[b]{2}{*}{ Forest } & \multirow[b]{2}{*}{ Sig. } & \multirow[b]{2}{*}{ OR } & \multicolumn{2}{|c|}{$\begin{array}{l}\text { Chi square test } 95 \% \text { para } \\
\text { OR }\end{array}$} \\
\hline & & & & & & Lower & Upper \\
\hline Age $<20$ years & 1.512 & 0.534 & 6.154 & 0.008 & 4.12 & 1.565 & 12.176 \\
\hline APP (Yes) & 1.293 & 0.164 & 61.867 & 0 & 3.643 & 2.64 & 5.027 \\
\hline Sitting position $(>30)$ & 1.826 & 0.747 & 64.944 & 0.031 & 4.484 & 2.512 & 6.092 \\
\hline IMC (If) & -0.008 & 0.184 & 0.002 & 0.965 & 0.992 & 0.692 & 1.422 \\
\hline Two or more puncture attempts & 1.713 & 0.634 & 8.174 & 0.002 & 6.2 & 1.76 & 21.1 \\
\hline Needle 20 and 22G (Yes) & 1.812 & 0.634 & 6.174 & 0.004 & 6.12 & 1.768 & 21.189 \\
\hline Age $<20$ years * BMl & & & 4.409 & 0.11 & & & \\
\hline APF $(\text { Yes })^{*}$ Age $<20$ years* BMI & -0.966 & 0.476 & 4.115 & 0.043 & 0.381 & 0.15 & 0.968 \\
\hline $\begin{array}{l}\text { APF }(\text { Yes })^{*} \text { Age }<20 \text { years }{ }^{*} \text { Two or more } \\
\text { puncture attempts }\end{array}$ & 1.715 & 0.647 & 44.944 & 0.031 & 4.484 & 2.512 & 6.092 \\
\hline Constant & -0.73 & 0.446 & 2.681 & 0.102 & 0.482 & & \\
\hline
\end{tabular}

\section{Discussion}

According to international reports, the incidence of dural post-puncture headache (CPPD) is very variable, ranging from 0.5 to $32 \%$; others report an incidence of 0.02 to $3 \%[1,11,12]$. In national studies reviewed, the incidence of this complication varies between 1.5 and $16.2 \%$ [13].

The investigation showed that females undergoing elective cesarean section with ages less than 25 years have a 4 times higher risk of developing dural post-puncture headache $(O R=4.16)$, results that coincide with that reported in the literature.

Lake Alfonso reported a higher incidence of CPPD between 15 and 35 years; while Choo Ubals obtained predominance in the group of 15 to 25 years, [1]. In general, all authors agree that headache is more frequent in young people and under 50s. After the fifth decade there is a sharp reduction in incidence, which can be attributed, among other factors, to loss of neural elements with age, and lower elasticity of cerebral blood vessels $[2,14,15]$.

The present investigation showed that the body mass index greater than 30 is not considered a risk factor for the appearance of dural post-puncture headaches, females subjected to elective cesarean sections. Studies report that for reasons that are still unclear, morbid obesity may decrease the incidence of post-puncture headache with an epidural needle [16]. Others refer to it as a dubious risk factor, stating that obesity would favor PDA, but at the same time the incidence of PDPH would decrease [17-19].

Researchers report that patients with a previous history of $\mathrm{PDPH}$ or migraine, or with headache before or during lumbar puncture, have a higher risk $[1,2,8,13,20]$. This coincides with the results of the present investigation, where obtained an $\mathrm{OR}=3.8$.

Other authors have stated that patients with a history of headache or PDPH, have a greater risk of presenting it, in some series incidents of between $19 \%$ and $70 \%$ [21,22] reflecting the predisposition of these patients.

As expected, the most direct influence on the development of the CPPD is the size of the needle used. The smaller the caliber of the spinal needle, the lower the incidence of headache $[17,19,23,24-26]$. In fact, the internal diameter of the needle is the dominant factor in the size of the hole produced in the dura and the velocity of the needle. runoff from the CSF. With the use of fine, very flexible and elastic needles, an introducer or other thicker needle should be used to facilitate its passage through the intervertebral ligaments, since the finer needles are technically more difficult to use $[1,2,27]$.

These results coincide with what was obtained in the present investigation where it was obtained that females where 20 and $22 \mathrm{G}$ needles are used have a 9.39 times higher risk factor of developing dural post-puncture headache.

The international data tell us of a lower incidence of CPPD when using needles of smaller caliber and of bevel in tip of pencil $[28,29]$.

The authors suggest that a greater number of LP attempts are associated with a higher incidence of PDPH because a larger hole is opened in the dura and the CSF output increases $[5,7-13,17,18,30]$ results that coincide with those obtained in the present investigation where the group of cases in which two or more attempts were made, have a 4.79 times higher risk of developing dural post-puncture headache [31]. 
Some studies have failed to demonstrate a significant correlation between the number of dural punctures and the incidence of post-puncture headache, questioning the hypothesis of CSF loss through the dura as the cause of headache [32,33]. 16 state that the insufficient statistical power of these studies was the cause for raising these claims, and in their study found that repeated punctures significantly increase the incidence of post-puncture headache $[34,35]$.

So far there are not enough reports in the medical literature that support the hypothesis that the incidence of post-puncture headache is greater when the patient is punctured in a sitting position versus lateral decubitus. Although theoretically and physically, it could be explained that the hydrostatic pressure at the puncture site is greater in the patient in the sitting position than in the patient in the lateral decubitus position, given that the hydrostatic pressure depends on the height of the CSF column at the site of the puncture and the density of it, and the clinical trials evidencing this theoretical speculation are limited, are reflected in an evident clinical difference $[1,36]$.

The design of the present study allowed to demonstrate that the lateral decubitus position was effective to reduce the incidence of CPPD compared to the sitting position [37,38,39].

The pressure of the CSF in the lateral position is 5 to $15 \mathrm{~cm}$ of $\mathrm{H} 2 \mathrm{O}$, while in the sitting and erect position it increases to $40 \mathrm{~cm}$ of $\mathrm{H} 2 \mathrm{O}$. This important difference in pressure should be considered to understand the pathophysiology of dural postpuncture headache. It should also be taken into account that CSF pressure increases during each uterine contraction, frequently reaching $60 \mathrm{~cm} \mathrm{H} 2 \mathrm{O}$ in the acme of a contraction $[40,41]$. To these changes we would have to add the elevation that can be produced due to the maternal efforts. These data explain why the CPPD is more frequent in the pregnant woman and also why it is better to perform the puncture in the left lateral decubitus position, avoiding the sitting position [42-44].

Despite this incidence of CPPD obtained in the study, we believe that its value does not contraindicate the use of regional anesthesia for cesarean section, because this technique offers lower morbidity and mortality in this population, compared with general anesthesia [45]. If the PDPH is presented, this does not imply greater disability for the patient, since its highest incidence is between mild and moderate, which yields with rest, hydration and non-opioid analgesics.

\section{Conclusion}

The age under 25 years and the history of previous headache are the risk factors dependent on the patient related to the appearance of post-puncture headache in obstetric patients undergoing elective cesarean section.

The needle diameter of 20 and 22G, the highest number of puncture attempts and the position of the seated patient are the risk factors dependent on the technique related to the appearance of post-puncture headache in obstetric patients undergoing surgery. elective cesarean section.

The body mass index higher than 30 was not a risk factor with the appearance of post-puncture dural headache.

\section{Recommendations}

The factors identified should be applied to the assessment of the risk of post-puncture headache in obstetric patients undergoing elective cesarean section.

Identify the influence of other factors (characteristics of the needle, direction of the bevel of the needle, angle of insertion of the needle, rotation of the needle within the epidural space, the experiences of the anesthetist, among others) with the appearance of post-headache dural function in obstetric patients undergoing elective cesarean section.

\section{References}

1. Chauca M, Hugo V (2010) Incidencia de cefalea post-punción dural en pacientes mayores de 18 años del servicio de traumatología de hospital provincial general docente de Latacunga en el período marzo a diciembre 2009. Médico General Tesis de grado; previo a la obtención del Título de: Médico General.

2. Plaza A, Rueda J (2014) Manejo en hospitalización de la cefalea post- punción dural en obstetricia.

3. Macarthur AL (2003) Neurological complications of regional obstetric anesthesia. Thech Reg Anesth Pain Manage 7: 229-234.

4. Loures V, Savoldelli GL, Alberque C, Haller G (2012) Posdural puncture cerebrospinal fluid leak presenting as an acute psychiatric illness. Br J Anaesth 108: 529-530.

5. Ghaleb A (2010) Postdural Puncture Headache. Anesthesiol Res Pract 2010: 1-6.

6. Kohenkampf RC, Nazar JC, Lacassie QHJ (2011) Anestesia general para operación cesárea: Beneficios, riesgos y complicaciones asociadas. Rev Chil Anest 40: 335-343.

7. World Medical Association Declaration of Helsinki (2013) Ethica Principles for Medical Research Involving Human Subjects. JAMA.

8. Jiménez MIS, Delgado JA, Hervella FD, García MLC, Pérez A, et al. (2011) Analgesia epidural obstétrica: fallos y complicaciones neurológicas de la técnica. Rev Soc EspDolor 18: 276-282.

9. Aquino LPG (2010) ¿Cuándo anestesia general vs neuroaxial en obstetricia?. Revista Mexicana de Anestesiologia 33: S45-S47

10. Headache Classification Subcommittee of the International Headache Society (2004) The International Classification of Headache Disorders: 2nd edition. Cephalalgia 24: 9-160.

11. Correa TL, Sánchez JCG, Montero FJS, Villoria CMV (2011) Cefalea Postpunción dural en obstetricia. Rev Esp Anestesiol Reanim 58 : 563-573.

12. Choi PT, Galinski SE, Takeuchi L, Lucas S, Tamayo C, et al. (2003) PDPH is a common complication of neuroaxial blockade in parturients: a meta-analysis of obstetrical studies. Can J Anesth 50: 460-469.

13. Padilla JMC (2012) Cefalea pospunción dural en la paciente obstétrica. Rev Cubana Obstet Ginecol 38: 256-268.

14. Gomelsky D (2014) Incidencia de cefalea postpunción dural y estudio de cohorte comparativo con la utilización de agujas quincke (traumáticas) no 27 vs agujas no 25 en pacientes obstétricas. Revista CAMbios 13: 22

15. Gomelsky MD (2014) Incidencia de cefalea postpunción dural con la utilización de agujas Quincke (traumáticas) no 27 vs agujas no 25 en pacientes obstétricas. Universidad San Francisco de Quito. 
16. Stein $\mathrm{MH}$, Cohen S, Mohiuddin MA, Dombrovskiy V, Lowenwirt (2014) Prophylactic Vs Therapeutic Blood Patch For Obstetric Patients With Accidental Dural Puncture - A Randomised Controlled Trial. Anaesthesia 69: 320-326.

17. Gomelsky D (2013) Seguridad del paciente en anestesia: complicaciones en sala de operaciones del Hospital Carlos Andrade Marín, de diciembre 2012 a noviembre 2013 comparación con año previo. Revista CAMbios 13: 22.

18. Venegas E, Correa L, Gomelsky D (2012) Laringoespasmo posextubación Comparación de la eficacia de la administración de lidocaína al $2 \%$ sin epinefrina (s/e) antes de la extubación y durante la inducción anestésica en la prevención del laringoespasmo en niños sometidos a cirugía oral. Rev CAM bios 12: 29-34.

19. Gomelsky D (2013) Exposicion en I Curso Actualización en Urgencias Clinico Quirurgicas, Terapia Intensiva, Manejo del Dolor con Avances en Medicinay Enfermeria. Tema: Dolor Crónico: fisiopatologia y manejo. Quito

20. Fernández MA, Ros J, Morales AV (2000) Fallos en la analgesia epidural obstétrica y sus causas. Rev Esp Anestesiol Reanim 47: 256-265.

21. Rucklidge MWM (2014) All Patients With A Postdural Puncture Headache Should Receive An Epidural Blood Patch International Journal Of Obstetric Anesthesia 23: 171-174.

22. Munoz SM, Arevalo EG (2013) Actuación ante una punción dural accidental (PDA). En Protocolos Asistenciales de la sección de Anestesia Obstétrica de la SEDAR. Ene Ediciones.

23. Fiala A, Furgler G, Baumgartner E, Paal P (2012) Delayed subdural haematoma complicated by abducens nerve palsy and cortical vein thrombosis after obstetric epidural anaesthesia. $\mathrm{Br} J$ Anaesth 108: 705-706.

24. Akin TS, Unal KC, Kaymak C, Basar H (2010) Treatment of postdural puncture headache with bilateral greater occipital nerve block. Headache 50: 869-881.

25. Atanassoff PG, Bande MC (2000) Anestesia subaracnoidea: 100 años de una técnica establecida. Rev Esp Anestesiol Reanim 47: 198-206.

26. Auroy Y, Narchi P, Messiah A, Litt L, Rouvier B, et al. (1997) Serious complications related to regional anesthesia. Anesthesiology 87: 479-486.

27. Andrea GS, Claudio NJ, Javier BE, Maximiliano ZH, Patricio MT, et al. (2014) Anestesia neuroaxial en trabajo de parto y cesárea en pacientes con antecedentes de mielomeningocele operado. Rev chil obstet ginecol 79: 531-536.

28. Loures A, Savoldelli G, Kern K, Haller G (2014) A typical headache following dural puncture in obstetrics. International journal of obstetrics Anesthesia 23: 246-252.

29. Ahmed AA, Adhikary S, Verbeek TA, Vaida S (2012) Use of Cosyntropin for Treatment of Refractory Post Dural Puncture Headache (PDPH): Case Report and a Suggested Algorithm. J Anesth Clin Res 3: 11.
30. Toledo P (2012) What's New In Obstetric Anesthesia: The 2011 Gerard W. Ostheimer Lecture Review Article. Int J Obstet Anesth 21: 68-74.

31. Higgins L (2014) Clasificación del Estado Físico de la American Society of Anesthesiologists (ASA). Anestesiología.

32. Agerson AN, Scavone BM (2012) Prophylactic Epidural Blood Patch After Unintentional Dural Puncture for the Prevention of Postdural Puncture Headache in Parturients. Anesth Analg 115: 133-136.

33. Lenelle L, Goffart BL, Dewandre PY, Brichant JF (2011) Les céphalées post-ponction durale: traitement et prevention. Rev Med Liège 66: 575-580.

34. Jabbari A, Alijanpour E, Mir M, Hashem NB, Rabiea SM, et al. (2013) Post Spinal Puncture Headache, An Old Problem And New Concepts: Review Of Articles About Predisposing Factors. Caspian J Intern Med 4: 595-602.

35. Butwick AJ (2012) 2012 Gerard W. Ostheimer Lecture - What's New In Obstetric Anesthesia? Int J Obstet Anesth. 21: 348-356.

36. Bayter A, Ibáñez F, García M, Meléndez HJ (2007) Cefalea postpunción en pacientes sometidas a cesárea bajo anestesia subaracnoidea. Eficacia de la posición sentada versus decúbito lateral. Ensayo clínico controlado. Rev colomb anestesiol 35: 121-127.

37. Fayard AF, Malinovsky JM (2013) Céphalées post-brèches méningées et blood-patch: aspects théoriques et pratiques. SFAR 32: 325-338.

38. Heesen M, Klöhr S, Rossaint R, Walters M, Straube S, et al. (2013) Insertion of an intrathecal catheter following accidental dural puncture: a meta-analysis. Int J Obstet Anesth 22: 26-30.

39. Russell IF (2012) A prospective controlled study of continuous spinal analgesia versus repeat epidural analgesia after accidental dural puncture in labour. Int J Obstet Anesth 21: 7-16.

40. Ghaleb A, Khorasani A, Mangar D (2012) Postdural Puncture Headache. Int J Gen Med 5: 45-51.

41. Gaiser RR (2013) Postdural Puncture Headache: A Headache For ThePatient And A Headache For The Anesthesiologist. Curr Opin Anesthesiol 26:296-303.

42. Nguyen DT, Walters RR (2014) Standardizing Management of PostDural Puncture Headachein Obstetric Patients: A Literature Review. OJAnes 4:244-253.

43. Nath G, Subrahmanyam M (2011) Headache In The Parturient Pathophysiology And Management of Post-Dural Puncture Headache. J Obstet Anaesth Crit Care 1: 57-66.

44. Peña MM, Loera JEM (2013) Realidades terapéuticas de la cefalea postpunción dural. Revista Mexicana de Anestesiología 36: S277S282.

45. Bradbury CL, Singh SI, Badder SR, Wakely LJ, Jones PM (2013) Prevention of post-dural puncture headache in parturients: a systematic review and meta-analysis. Acta Anaesthesiol Scand 57: 417-430. 